\title{
Notes on the Karatepe Storm-god Tarhunza Usanuwami and Baal Krntryš
}

\section{Karatepe'nin Fırtına Tanrısı Tarhunza Usanuwami ve Baal Krntryš Üzerine Notlar}

\author{
Faris Demir ${ }^{1}$ (1)
}

1Osmaniye Korkut Ata University, Faculty of Arts and Sciences, Department of Archaeology, Osmaniye, Turkey

\section{ORCID ID: FD. 0000-0001-8370-4350}

Sorumlu yazar/Corresponding author: Faris Demir,

Osmaniye Korkut Ata University, Faculty of Arts and Sciences, Department of Archaeology,

Osmaniye, Turkey

E-mail: farisdemir@gmail.com

Başvuru/Submitted: 21.04.2021

Revizyon Talebi/Revision Requested: 26.05.202 Son Revizyon/Last Revision Received: 27.05 .2021 Kabul/Accepted: 18.07.2021

Atıf/Citation: Demir, F. (2021). Notes on the Karatepe Storm-god tarhunza usanuwami and baal krntryš. Anadolu Araştırmaları-Anatolian Research, 25, 87-101.

https://doi.org/10.26650/anar.2021.925349

\section{ABSTRACT}

The Karatepe storm god has been defined in Luwian inscriptions as Tarhunza Usanuwami, and in the Phoenician version as Baal Krntryš. The meaning of the Krntryš epithet still maintains its mystery. Location names, names and adjectives with weak probability that have been proposed by some researchers do not provide a convincing explanation. The main gods of the Neo-Hittite provinces and the main features of these gods can be different, and neglecting the Karatepe reliefs and inscriptions and looking for cult characteristics outside the region can cause wrong interpretations. There is no study in which the Usanuwami and Krntryš epithet of the storm god has been investigated in all its features. In this study, suggestions having a high probability for the word Krntryš are presented in line with the iconographic features of the Karatepe storm god. These suggestions are the combination of the words for granary (Luwian karuna, Phoenician 'qrnt) and wine and vineyard/wine warehouse (Luwian tuwarsa-tuwarisa, Phoenician trš, plural tryš).

Keywords: Karatepe Azatiwata, storm god, Tarhunza Usanuwami, Baal Krntry̌̌

öz

Karatepe Fırtına Tanrısı Luwice yazıtlarda Tarhunza Usanuwami, Fenikece yazıtlarda Baal Krntryš olarak belirtilmiştir. Krntryš epithetinin anlamı gizemini hâlâ korumaktadır. Bazı araştırmacılar tarafından önerilen olasıığı zayıf yer adları, isim ve sıfatlar ikna edici bir açıklamaya sahip değildir. Geç Hitit kentlerinin öncelikli tanrıları ve bu tanrıların öncelikli olduğu yönleri farklı olabilmektedir. Karatepe kabartmaları ve yazıtlarının göz ardı edilerek kült özelliklerinin bölge dışında aranması hatalı yorumlara neden olmaktadır. Fırtına Tanrısı'nın Usanuwami ve Krntryš epithetinin tüm yönleriyle araştırıldığı kabul gören bir çalışma bulunmamaktadır. Bu çalışmada, Karatepe Fırtına Tanrısı́nın ikonografik özellikleri doğrultusunda Krntryš kelimesi için olasılığı yüksek öneriler sunulacaktır. Bu öneriler tahıl deposu (Luwice karuna, Fenikece 'qrnt), şarap ve üzüm bahçesi/şarap deposu (Luwice tuwarsa-tuwarisa, Fenikece trš çoğul tryš) kelimelerinin birleşimidir.

Anahtar Kelimeler: Karatepe Azatiwata, Fırtına Tanrısı, Tarhunza Usanuwami, Baal Krntryš 


\section{Introduction}

Karatepe/Azatiwataya was discovered in what is today the province of Osmaniye, in modern Turkey, by Professor Helmuth Bossert and his team in 1946 (Bossert and Çambel , 1946, pp.1-15). It is located on the northeast side of what was then the Adanawa/Que country, on a hill on the western side of Ceyhan River. In excavation works carried out in 1947, numerous basalt orthostats decorated with inscriptions and reliefs belonging to the castle entrance gates were unearthed (Alkım, 1948, pp.533-48; Bossert et al., 1950, pp.184). Bilingual inscriptions are repeated in Hieroglyphic Luwian and in Phoenician on the orthostats of the two doors, and Phoenician that is slightly different from the others is found on the statue of the storm god. The Karatepe inscriptions were inscribed by Azatiwata (pp.705-696?), as authorized by the Adanawa king Awariku, and Azatiwata later established his own kingdom. In his inscriptions Azatiwata introduces himself, explains his important achievements, which he has made with the help of the gods, orders that sacrifices be made to the gods for the continuation of his grain and wine supply, abundance, health and long life and, finally, curses those who want to take his castle.

The storm god Tarhunt/Tarhunza was chief deity of the Neo-Hittite Luwian pantheon (Hutter 2003: 220). In the Neo-Hittite provinces, the primary features of the storm god show variations and they are iconographically depicted in two different ways. The storm god is sometimes represented as a warrior carrying weapons such as a double-headed axe, trident lightning, sword, and mace, and sometimes as a force bringing abundance holding grain ears and bunches of grapes (Kohlmeyer, 2000, pp.1-8; Hawkins, 2000, pp.295). The significant features of the storm god are that he carries clouds and winds, and that he makes crops and vineyards productive. The features of the Karatepe storm god and the meaning of Krntryš, which is mentioned in the Phoenician texts, are not known. The epithets of the gods contain the meaning represented by the attribute, or indicate cities such as Tarhunzas of Aleppo and Tarsus Baal. However, until now a word similar to Krntryš or to a city name could not be found.

Many scholars believe that the Krntryš epithet is a non-Semitic word (Barnett, 1948, pp.61; O’Callaghan, 1949, pp.189; Dupont-Sommer, 1949, pp.222; Gibson, 1982, pp.60). For this reason, city names and adjectives with weak probability were proposed for the epithet and an adequately convincing explanation could not be made. Alt (1948, pp.121124), Barnett (1953, pp.142) and Vattioni (1968) have suggested Kelenderis city; Alt (1950, pp.282) suggested Krindion city and the name of Kurunta; Dupont-Sommer (1948, pp.173) have suggested the combination of the Greek kápavos ('chief') and Tarse; Honeyman (1948, pp.43-57) has suggested the kuirwan(a)-tarayas 'lord of Tarsus' combination; and Bossert

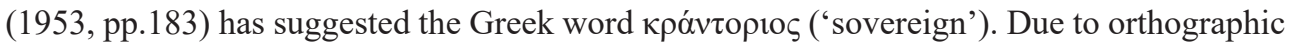
problems, Lebrun (1992, pp.58-59) has objected to the word -tryš becoming Tarse. He 
suggests isolating the initial segment krn, comparing Akkadian kurinnu with the remaining letters -tryš, which are being Luwian suffixes. Röllig (1967, pp.42) has pointed out that the word Kurunta is a king's name in Hittite and subsequently proposed the combination of KrnTarhuis. He has associated the word krn with the epithet bēl-kurrinni, connected to the KahatTešub (Röllig, 2001, pp.49). Weippert (1969, pp.211-213) has suggested the combination of kr-natariyassis, Tarhuis being a Luwian adjectival form that is not verified.

Yakubovich (2008, pp.42) has interpreted the Krntryš epithet as kuranatarīs < kuwalanatallīs ('Baal of the Army') and has Luwian equivalente it with "Highly Blessed" Tarhunt. Based on recent epigraphic evidence, Lawson Younger (2009, pp.16-18), referring to $\operatorname{Kur}(r) a$, has suggested the combination of kr-ntryš and has mentioned that the second word could be an adjective or the name of a place. Finally, Schmitz (2009, pp.119-60) has transformed the Archaic Greek word корvvๆ ('mace') into korunētērios ('mace bearing') in an etymologically invalid form, and has used the storm god of Aleppo as evidence. Yakubovich (2015, pp.39) has stated that the otherwise absent usage of the korunētērios word form weakened this suggestion. Röllig (2011, pp.128) was generally conservative in all cultures, and especially in the area of religion. In foreign languages, gods' names could only be adopted after a long acculturation period and cannot be assumed here under any condition.

It is seen that when researchers suggest a word or consider probabilities they make important logical mistakes. Although Iron Age cities had their own gods, different city names were proposed and it was asserted that in place of words widely known in Phoenician texts, a foreign word that was never used before has been employed. The pronunciations and meanings of the suggested words are not similar to the words in Phoenician and Luwian. Epithets bear the meaning represented by attributes; for this reason the suggestion of an attribute is of weak probability. Furthermore, many suggestions have relations with inscriptions and reliefs that are contextual findings. Karatepe describes itself in picture language, pictorial writing and alphabetic writing. Karatepe should be correlated with the function of the storm god and the meaning it has, which are subjects mentioned in reliefs and inscriptions. In this study, the method for the resolution of the Krntryš epithet is based upon the epigraphic analysis of features obtained from iconographic expression.

\section{Interpretation of the Storm God Statue and the Reliefs of the Gods}

The iconographic interpretation of the gods in the Karatepe reliefs, their usage frequency and the analysis of their relations with each other will contribute to revealing a picture of the storm god. A monumental statue of the storm god was placed within the castle right behind the southeast gate (Figs. 1-2). The area where the sculpture was placed must be a sanctuary where religious ceremonies were held (Alkım, 1950, pp.682). The base of the statue consists of two bulls and a small male figure between them holding the necks of the bulls. Bull 
figures are a known characteristic of the storm god. The arms of the god are bent at the elbows on both sides, and the hands are extended forward with fists. He carries a broken object that is unidentified in his two hands. He wears a simple, long tunic dress that is tightly wrapped around his body and goes down to his ankles, and he has a diagonal sash from his left shoulder to the bottom of his right breast (Çambel and Özyar, 2003, pp.114-115). There is an inscription in Phoenician on the ceremonial dress. The inscription starts at the front of the sculpture and continues from right to left and from the top towards the bottom, and ends at the side of bull that is at the left of the base. The god that is depicted according to this inscription is Baal Krntryš. The objects held by the storm god have not survived to this day. Therefore, the prominent features of the god cannot be accurately determined. Ceremonial dress shows that the warrior aspects of the god are not at the forefront in this representation.

There are many deities on the Karatepe orthostats, but there is no title or symbol decorated with horns indicating the gods. Depictions of gods are given as an indicator of superiority, as in the Ivriz rock relief, larger than the human figure and the height of the orthostat. The storm god has been depicted at the southern gate western wall on the SV1-4 numbered orthostat (Fig. 3). The god, shown with a beard, wears a plain tunic dress that reaches his knees and a conical headdress. The god who is standing on the bull holds a rabbit and a hawk in his hand in a way we have not seen before. Depictions of the storm god standing on the bull are seen in Karaçay, Cekke (Orthmann, 1971, Pl. 5d), Ahmar/Qubbah (Bunnens, 2006; Figs. 5-20) and Arsuz 2 reliefs (Dinçol et al., 2015; Figs. 3-11). But the god carrying a rabbit and hawk in his hand is a characteristic of (K)runtiya, who was known as the god of the hunt and god of the deer. The hunting god that is depicted on deer in the Arslantepe, Karasu and Gölpınar (Kulakoğlu, 2001; Fig. 2) reliefs, he carries a rabbit and hawk in the Yeniköy relief (Orthmann, 1971, Pls. 14f, 41b, 58c). Mention of Tarhunza and Runza together in the Karatepe inscriptions provides additional evidence that this depiction represents both of these gods. The combination of the storm god with other gods is seen in the Ivriz rock relief (Hawkins, 2000, P1. 295). In this relief, the storm god holding the grain ear and the bunch of grapes represents both the grain god and the wine god.

The presence of the SV1-4 storm god relief next to the banquet scene depicted on the SV12 and SV1-3 orthostats allows us to obtain important clues about the god (Fig. 3). Servants carrying food, musicians and the sacrifice scene depicted in the reliefs are associated with Hittite royal rituals. At the bottom part of the banquet scene, a bull and a sheep are being sacrificed. In KARATEPE 1, §\$47-48 - Phu/A II 18-19 + Phu/A III 1-2 (Hawkins, 2000, pp.54; Röllig, 1999, pp.52) inscriptions there are orders to sacrifice an ox once a year in honour of the storm god Tarhunza [...]/Baal Krntryš, to sacrifice a sheep at harvest time and to sacrifice a sheep at vintage time. Inscriptions and reliefs show that the god for whom sacrifices are made is depicted on the orthostat numbered SVl-4 (Fig. 3). 
Depictions of the hunting god carrying a rabbit and hawk are repeated four times, one after another, on orthostats numbered SK1-15, SKl-16 and SKl-17 (Fig. 4). Other depictions that may be related with the hunting god are seen on orthostats numbered SKr-18, NVr-4, NVr-5, NVr-7, NVr-11, NVl-10, NKr-15 and NKl-4 (Çambel and Özyar, 2003, pp.18-211). The Tyre god Milqart, who is depicted on orthostat number NKl-6, carries a lion. Milqart can be seen in areas where Phoenicia influence was widespread (Blois and Spek, 2019, pp.58; Fig. 5.3; Winter, 1979, pp.136-140). At the northern gate western wall on orthostat numbered NVr-12, a male figure with a weapon carries a lion and hawk and represents Milqart and Runza/Rešep. Milqart and Rešep, who are Phoenician gods, are gods that correspond to the Luwian god Runza in respect to their features. Among the Karatepe deities are depictions of Egyptian origin, including the breastfeeding goddess (NVr-8) and the Bes (NVr-2, NKr-2), who have protective and fertility features. The iconography of these sculptural works shows that the storm god of the city was correlated with the hunting god.

\section{Interpretation of Inscriptions and Word Analysis}

Interpreting and analysing the Karatepe inscriptions will make important contributions to determining the characteristics of the god. The Azatiwata text contains the names of Tarhunza, Baal, Baal Krntryš, Baal Šmm (Šamem), Runza/Rešep Șprm (Șiporim), El-Creator-of-Earth, the sun god, the grain god and the wine god (Hawkins, 2000, pp.48-58; Röllig, 1999, pp.5068). Looking at the usage frequency of gods it is seen that in the Luwian text, Tarhunza occurs eight times, the sun god occurs twice, the grain god occurs twice, the wine god occurs twice and Runza and Ea occur once, and in the Phoenician texts, Baal occurs twelve times, Rešep Șprm occurs twice, and El-Creator-of-Earth and the sun god occur once. The usage frequency indicates the leading god in the city was the storm god and other additional gods occur to a lesser degree. The Krntryš epithet occurs five times on the gates, four times on the statue, and the Šmm epithet occurs once on the north gate. This data should be interpreted together with the features that stand out in the Karatepe texts interpretation:

I am Azatiwata, the Sun-blessed man, servant of Tarhunza/Baal

Tarhunza/Baal made me mother and father to Adanawa

And I filled the Paharean granaries and I made army upon army, ... all by Tarhunza/Baal and the gods.

So Tarhunza/Baal and Runza/Rešep Șprm asked me to build this fortress and I built it ... I caused Tarhunza/Baal Krntryš to dwell in it and every river-land will begin to honour him: the year an ox, and at the ploughing a sheep and at the vintage a sheep.

And may Tarhunza Usanuwami/Baal Krntryš and this fortress's gods give to him, to Azatiwata, long days and many years and good abundance, ...

And so let this fortress become (one) of the grain god and the wine god ...

May celestial Tarhunza/Baal Šmm, the celestial Sun, and all the gods eliminate that kingdom and ... 
In the first part of the text, Azatiwata states that he is man of the sun god and the servant of Tarhunza/Baal, he has made himself mother and father of city of Adanawa, that he filled the Paharean/Paar granaries with the help of this god and that he develops his army. In the middle section of text, it is explained that Tarhunza/Baal and Runza/Rešep Șprm requested that a castle be built and that it was made with the help of these two gods. The name Azatiwataya was given to the castle and the sculpture of the storm god was placed there. After the storm god sculpture was established it is understood that the god of the castle is Tarhunza Usanuwami/Baal Krntryš. It is ordered that offerings be made to these gods and, in return, the god is asked to be the grain god and the wine god (house) for longevity, health, abundance, wealth, victory, success and superiority. In the final section of text, for damnation, help is requested from Tarhunza/Baal Šmm, god of the sun and all the gods. The usage of the epithet Šmm in the damnation part provides important criteria of differentiation and important clues about characteristics of the god. The epithet of Șmd that is used in the damnation part of the Zincirli (Sam'al/Y'dy) Kilamuwa inscription (O'Connor, 1977, pp.20) has not been used here. According to textual interpretation, it is seen that the storm god is correlated with the hunting god Runza/Rešep Șprm, the grain god and the wine god.

The storm god Tarhunza/Baal is the god of war and abundance, according to its general characteristics. It provides important clues to the epithets used for the Karatepe storm god's productivity-related features, such as longevity, health, abundance, wealth, victory, success, hunting, grain and wine. The counterpart of Tarhunza, who is the god mentioned in the Luwian inscriptions KARATEPE 1, $\$ 51$ (Hawkins, 2000, pp.55), is Baal Krntryš in the Phoenician inscriptions Phu/A III. 4, [PhSt C III 19 = Pho/B II 8] (Röllig, 1999, pp.5264). The Karatepe inscriptions are the Phoenician and Hieroglyphic Luwian versions of a text. These parallel versions complete missing parts of versions and partially correct wrong inscriptions. The ARHA Usanuwami epithet specified on the north gate of the storm god has been corrected as ARHA (BONUS) Usanuwami on the south gate. The fact that ARHA (BONUS) Usanuwami is about abundance fits the sense of the very blessed and helps in the interpretation of the Krntryš epithet.

KARATEPE 1, § 51 (Hawkins, 2000, pp.55)

$\mathrm{Hu}$.

pi-ia-tu-há-wa/i-tu-u (DEUS)TONITRUS-hu-za-sá ARHA u-sa-nú-wa/i-mi-sá za-sihá-wa/i |(“CASTRUM”) há<+ra/i>-na-sá-si DEUS-ní-zi (LITUUS)á-za-ti-wa/i-tà-ia \| "LONGUS"-ta ${ }_{5}$-ia (DIES) há-li-ia mi-ia-ti-zi-ha || (ANNUS)u-si-zi sa-na-wa/i-sá-ha-wa/i || tá-mi-hi-sá

Ho.

|pi-iá-tù-há-wa/i-tu ${ }_{4}$-u (DEUS)TONITRUS-hu ${ }_{\mathrm{x}}-\mathrm{za}_{4}$-sa |ARHA |(BONUS)u-sa-nú-wá/ímí-sá za-i'-si-i-há-wá/í || (“CASTRUM”)há+ra/i-ní-sà-si |DEUS-SA 4 -zi I(OCULUS) á-za-tí-wá/í-tà-ia ("LONGUS”) a+ra/i-ia |(“DIES”)há-li-iá |mì-ia-tí-zi 4 -há |ANNUS-si-zi |(BONUS)sa-na-wà/ì-sa-há-wá/í | tá-mi-hi-sá 
And may Tarhunza Usanuwami and this fortress's gods give to him, to Azatiwata, long days and many years and good abundance

Phu/A III. 4-6, [PhSt C III 19-20 = Pho/B II 7-10] (Röllig, 1999, pp.52-64)

ltty b'l krntryš wkl 'In qrt l'ztwd 'rk ymm wrb šnt wrš̀t n'mt

So that Baal Krntryš and all the gods of the city give to Azatiwada length of days and multitude of years and good abundance

Although the function of the Luwian Hieroglyphic ARHA logogram is not clear, it is also used on objects with names such as grain and wine (gods) in the inscriptions of SULTANHAN $\S \S$ 6-7 (Hawkins, 2000, pp.466) and KARKAMIŠ A2 $\S 7$ (Hawkins, 2000, pp.109). The hieroglyphic (BONUS) defines welfare and goodness logographically. (DEUS)BONUS in the inscriptions at Karkamiš and Karatepe and on two stelae found at Tell-Tayinat represents the good god and the grain god known as Kumarma, and is often associated with the wine god (DEUS)VITIS-títi known as Tipariya (Hawkins, 2000, pp.55-109; Dinçol et al., 2015, pp.64; Weeden, 2018, pp.349). In the Karatepe Luwian inscriptions the name of the wine god corresponding to (DEUS)VITIS-sá-há and (DEUS)VITIS-tí-ti-há, appears in the Phoenician inscription as trš (Hawkins, 2000, pp.55; Röllig, 1999, pp.51-60).

The plural of trš (wine) is tryš (wines/vineyard/wine warehouse) and it forms the second part of the Krntryš epithet. In Phoenician grammar, third singular names can be made plural with the letter-y yod (Krahmalkov, 2001, pp.125). Although it is rare, the feminine third singular form mlkt and feminine third plural form mlkyt ('queens') can be shown as examples of this transformation. Furthermore, in the Karatepe inscriptions Phu/A I $\$ 13-\mathrm{PhSt} / \mathrm{C}$ II 1 (Röllig, 1999, pp.50-62), the feminine plural of the word ḥmt was used as ḥmyt ('walls). To verify the correctness of this application both in respect to grammar and meaning, it would be sufficient for us to look at Aramaic words. In Aramaic, the word trbyṣ ('garden') (Lete and Sanmartín, 2015, pp.864) is similar to the Phoenician tryš. In addition, the Luwian word tuwarisa is similar to the Phoenician tryš. The -tryš ending of the Krntryš epithet shows that this composite word is at least semi-Semitic and it was formed from at least two words. The Karatepe Phoenician language used the Tyre/Sidon dialect (Garbini, 1977, pp.289; Röllig, 1983, pp.379).

SULTANHAN §§ 6-7 (Hawkins, 2000, pp.466)

$\S 6 \mid$ wa/i-ti-i |mara/i+ra/i-wa/i-li-sá-a [l](“PES”)pa-da |ARHA-a |la+ra/i-ta

$\S 7$ |(“VITIS”)wa/i-ia-ni-sa-pa-wa/i-a |za-ri+i || |sa-na-wa/i-ia-ta-a

$\S 6$ and the grain was abundant at his foot

$\S 7$ (and) the vine was good too here

KARKAMIŠ A2 $§ 7$ (Hawkins, 2000, pp.109; Weeden, 2018, pp.351)

$\S 7$ wa/i-ta-'a mi-ia-za-' LITUUS+AVIS-ta-ni-ia-za |REGIO-ni-i a-tá (DEUS)BONUS-na (DEUS)VITIS(-)ti- PRAE-ia-ha|| ARHA (CAPERE ${ }_{2}$ )u-pa-ta

and in my days, he (Tarhunza) established in the land the grain god and (the wine god) Tipariya 
KARATEPE 1, $§ 53$ (Hawkins, 2000, pp.55)

$\mathrm{Hu}$.

REL-pa-wa/i za (“CASTRUM”)há+ra/i-ní-sà-||za i-zi-ia-ru (DEUS)BONUS-sa (DEUS) VITIS-sá-há

Ho.

|REL-i-pa-wà/ì |za-' [...||...] (DEUS)VITIS-tí-ti-há so let this fortress become (a place) of the grain god and the wine god Phu A/III 7 = PhSt C IV 6 [= Pho B/II 11] (Röllig, 1999, pp.51-60) $w$-kn hqrt z b'lt šb' w-trš and may this city be mistress of satiety (grain) and wine

TELL TAYINAT, ARSUZ 1-2 (Dinçol et al., 2015, pp.64)

A1 $§ 4$ (DEUS)BONUS-wa/i-mu (DEUS)VITIS-ia-sa-ha "L.286"-li- tà

A2 $§ 4$ (DEUS)BONUS-pa-mu (DEUS)VITIS “L.286”+ra/i-li- tà

The grain god and the wine god were nice to me

I have determined that the Karatepe storm god is correlated with the hunting god, the grain god and the wine god. The inscriptions state that Tarhunza/Baal and Runza/Rešep ordered the castle to be built and that it was built with the help of these gods, and it is understood that iconographically the castle has been dedicated to these gods. The Luwian Kruntiya name is similar to the Krntryš epithet written in Phoenician. But correlating the Krntryš epithet directly with Kruntiya and the -tryš combination would be quite problematic, both in regard to semantic relationships and word structure. In the Karatepe inscriptions, KARATEPE $1, \S 48$ - Phu/A III 1-2, ordering sacrifices to the storm god at harvest and vintage times strengthens the god's relationship with agriculture. The word krn is similar to the Akkadian karānum ('vineyard') and the Hittite GIŠGEŠTIN-karānu ('wine') (Huehnergard, 2000, pp.81-501). However, the relationship of the Krntryš epithet with vintage and the wine god is provided by -tryš and what has remained is to question the relationship of the word krn with harvest, grain, land and prairie. If we go to the line of KARATEPE 1, $§ 7$ (Hawkins, 2000, pp.49) - Phu/A I.6 (Röllig, 1999, pp.50) where it is mentioned that Azatiwata fills the Paharean granaries, we will get closer to this outcome. These lines contain the Luwian karunazi ('granaries', singular karuna) and Phoenician 'qrt ('granaries', singular qrnt) words for the word krn.

KARATEPE 1, § 7 (Hawkins, 2000, pp.49)

$\mathrm{Hu}$.

|(“MANUS<”)su-wá/í-ha-ha-wá/í |pa-há+ra/i-wa/i-ní-zi (URBS) $\mid(<“>* 255 ”) k a-r u-n a-z i$ Ho.

[ ... ]-ha+ra/i-wa/i-n[í-z]i(URBS) (*255)ka-ru-na-zi

and I filled the Paharean granaries

Phu/A I. 6 (Röllig, 1999, pp.50)

wml' 'nk 'qrtp'r

and I filled the granaries of Paar 
A variation of the Luwian karuna granary has been documented with kaluna in the MARAŞ 8 (stele), $\S 7$ (Hawkins, 2000, pp.253) inscription. In Phoenician, 'qrt is a plural word and it is required to determine its singular form and other usages. Röllig (1999, pp.58) states that the 'qrt word is a hapax legomenon; the word root ends with -t by connecting with g/qrn in 'qrnt feminine form, and the 'Ayin letter at the beginning of word remains unexplained. The Ugaritic grn ('threshing floor') (Gordon, 1943, pp.65; Swiggers, 1980, pp.338; Lipiński, 1997, pp.241, 31.14; Sivan, 2001, pp.56-78) and the Akkadian words q/ gurunnu ('heap, mound'), qarītum ('granary') and garānu/karānu ('to store') are related with 'qrnt (Huehnergard, 2000, pp.441-514; Bomhard and Kerns, 2011, pp.395; Harper, 2007, pp.161). The 'Ayin letter can become apheresis when words have suffixes, just like in the example of 'dn / dnnym, and some words, like 'nḥn / nḥn (Krahmalkov, 2001, pp.39), can be used in two different forms without any transformation. The Luwian karuna word is similar to the Phoenician word 'qrnt. In addition, Karatepe was built on a settlement that was previously used as a granary (Alkım, 1950, pp.681). The correlation of Krntryš with grain and wine both for the Luwian and Phoenician words has been proven.

It is understood that the Luwian Usanuwami 'Highly-Blessed' epithet of the storm god is more than two consecrations. For this reason, it must be correlated with the storm god of the country of Adanawa with which it is affiliated. In the Çineköy inscription (Tekoğlu et al., 2000, pp.968-994) the storm god is defined as Tarhunt/Baal Kr. The Kr epithet is also seen in the Cebelireis (Cebel Ires) inscription (Mosca and Russell, 1987, pp.14; Röllig, 2008, pp.52) and this provides important evidence that the god is related to the prairie, land and vineyard. The word kr passes as karu in Akkadian and it means garden and pasture (Tomback, 1978, pp.149).

ÇİNEKÖY §§ 16-18 (Tekoğlu et al., 2000, pp.994)

... [k]n b'l kr štq yš'šb'w [kl] n'm 'l mlk h'w'p bn

... b'l kr to this king tranquillity(?), deliverance, abundance, and good

CEBELİREİS (CEBEL İRES) $\S \S 4 \mathrm{a}-5 \mathrm{~b}$ (Mosca and Russell, 1987, pp.14)

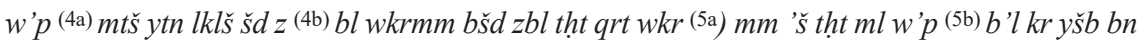
and Mutaš gave to Kulaš the field of the Prince and the vineyards within the field of the Prince below the town as well as the vineyards below ML and he (Mutaš) settled Baal $\mathrm{Kr}$ in it

The storm god was also worshiped in the city of Sidon with the Baal $\mathrm{Kr}$ epithet (Barnett, 1969, pp.10-11; Lipiński, 1970, pp.43; Elayi, 1988, pp.547; 1990, pp.64). The political relationship of Adanawa/Que with the Phoenician cities of Tyre and Sidon has also been proven religiously. The Sidon Baal Kr deity is related to Rešep and the Tyre god Milqart. In the Karatepe inscriptions it is stated that Tarhunza/Baal and Runza/Rešep ordered the castle to be built and it was built with the help of these gods, and in the inscriptions there are many depictions of Runza/Rešep and also the Tyre god Milqart. Lipiński (1970, pp.43) first interprets the Kr epithet as kûr ('furnace') in Hebrew. However, later he argues that Kura was 
a god of harvest and agriculture because the deity's name is non-Semitic (it meant 'grinding stone', derived from Old Sumerian Kura) and thus the god's cult was a fertility cult, linked to the myth of the dying and rising deity, resulting in the association with Milqart (Lipiński, 1995, pp.239-240).

Lipiński's determination that Kura was the god of harvest and agriculture is in complete harmony with the findings proposed for the Krntryš epithet in this article. Bunnens $(2006,128$, pp.88) has asserted that the name $\mathrm{Kr}$ is an abbreviated form of Krntryš. Lawson Younger (2009, pp.1-18), in his article, has analysed the Kur(r)a god in detail and has evaluated its relationship with the Krntryš epithet. According to the characteristics of the storm god, there is a high probability that the $\mathrm{Kr}$ epithet is the same as Krntryš. The $\mathrm{Kr}$ epithet has probably been transformed into Krntryš by taking on the characteristics of the grain god, the wine god and the hunting god and in the Luwian inscriptions it is defined as Tarhunza ARHA (BONUS) Usanuwami "Highly-Blessed".

\section{Conclusion}

In conclusion, the Karatepe storm god Tarhunza Usanuwami is correlated with the Ivriz rock monument, which is depicted iconographically, and combinations of the grain god and the wine god as the storm god Tarhunza Tuwarisa in the Sultanhan inscription. In antiquity, grain and wine were generally the symbols of efficiency and welfare. On the coinage of Tarsus dating from the Late Classical and Early Hellenistic periods, the relationship between the grain god, the wine god and the hunting god can be observed. The god sits on a throne in Baaltars (Baal of Tarsos) depictions holding a grain ear, a grape bunch and an eagle (Pohl, 2004, pp.63-73; Bing, 1998,41-pp.76). On the reverse of these coins, a lion attacks a bull, being the attribute of the storm god, or a deer, being the attribute of the hunting god Kruntiya. The cult of fertility and agriculture in Cilicia was reflected in the Roman Imperial Period as Zeus Karpotrophos, Zeus Kronos, Dionysos Kallikarpos, Demeter Karpotrophos and the good god "Luwian (DEUS)BONUS" Agathos Theos (Sayar, 1999, pp.140144). According to inscriptions and iconography it is understood that this god provides welfare, health, longevity, abundance, and plenty of food, grain, wine, sheep and goats.

Peer-review: Externally peer-reviewed.

Conflict of Interest: The author has no conflict of interest to declare.

Grant Support: The author declared that this study has received no financial support.

\section{References}

Alkım, U. B. (1948). Karatepe Kazıları. Excavations at Karatepe. Belleten, 12(47), 533-548.

— (1950). The Fifth Season's Work at Karatepe. Belleten, 14(56), 677-682.

Alt, A. (1948). Die geschichtliche Bedeutung der neuen phönikischen Inschriften aus Kilikien. Forschungen und Fortschritte, 24, 121-124. 
— (1950). Die phönikischen Inschriften von Karatepe. Die Welt des Orients, 1(4), 272-287.

Barnett, R. D. (1953). Mopsus. Journal of Hellenic Studies, 73, 140-143.

- (1969). Ezekiel and Tyre. Eretz-Israel: Archaeological, Historical and Geographical Studies, 9, 6-13.

Bing, J. D. (1998). Datames and Mazaeus: The Iconography of Revolt and Restoration in Cilicia. Historia: Zeitschrift Für Alte Geschichte, 47(1), 41-76.

Blois D. L., Spek, R.J.V.D. (2019). An Introduction to the Ancient World. Third Edition, Routledge, London and Newyork.

Bomhard, A. R., Kerns, J. C. (2011). The Nostratic Macrofamily: A Study in Distant Linguistic Relationship. Walter de Gruyter.

Bossert, H. T. (1953). Die phönizisch-hethitischen Bilinguen vom Karatepe, 4. Fortsetzung Jahrbuch für kleinasiatische Forschung, 2, 167-188.

Bossert, T. H., Çambel, H. (1946). Karatepe: Yeni Bir Eti Harabesi (İlk Rapor). İstanbul Üniversitesi Edebiyat Fakültesi, Eski Önasya Kültürleri Araştırma Enstitüsü Yayınları 1, İstanbul.

Bossert, T. H., Alkım, U. B., Çambel, H., Ongunsu, N., Süzen, İ. (1950). Karatepe Kazıları Birinci Ön Rapor. Die Ausgrabungen auf dem Karatepe Erster Vorbericht. Türk Tarih Kurumu, Ankara.

Bunnens, G. (2006). A New Luwian Stele and The Cult of the Storm - God at Til Barsib - Masuwari. Leuven - Paris - Dudley: Peeters.

Çambel, H., Özyar A. 2003: Karatepe-Aslantaş Azatiwataya. Die Bildwerke. Mainz Am Rhein: Verlag Phlipp von Zabern.

Dinçol, B., Dinçol, A., Hawkins, J., Peker, H., Öztan, A., Çelik, Ö. (2015). Two new inscribed Storm-god stelae from Arsuz (İskenderun): ARSUZ 1 and 2. Anatolian Studies, 65, 59-77.

Dupont-Sommer, A. (1948). Azitawadda, Roi Des Danouniens: Étude sur les inscriptions phéniciennes de Karatepe. Revue d'Assyriologie et d'archéologie orientale, 42(3.4), 161-188.

- (1949). Le Déchiffrement des Hiéroglyphes Hittites Et Les Inscriptions Bilingues De Karatepe. Revue Historique, 201(2), 213-223.

Elayi, J. (1988). A Phoenician Vase Representing the God Milqart. dans Baghdader Mitteilungen, 19, $545-547$.

— (1990). Sidon, cité autonome de l'empire perse. 2nd Edition, Paris.

Garbini, G. (1977). I dialetti del fenicio: AION, 37, 283-294.

Gibson, J. C. L. (1982). Textbook of Syrian Semitic Inscriptions. Vol. 3, Phoenician Inscriptions. Oxford: Clarendon.

Gordon, C. (1943). The Poetic Literature of Ugarit. Orientalia, 12, nova series, 31-75.

Harper, R. F. (2007). The Code of Hammurabi: King of Babylon, About 2250 B. C. Wipf and Stock Publishers, Eugene, Oregon.

Hawkins, J. D. (2000). Corpus of Hieroglyphic Luwian Inscriptions 1: Inscriptions of the Iron Age. Berlin/ New York, de Gruyter.

Honeyman, A. M. (1948. Phoenician Inscriptions from Karatepe. Le Muséon, 61, 43-57.

Huehnergard, J. (2000). A Grammar of Akkadian. Eisenbrauns, Winona Lake, Indiana.

Hutter, M. (2003). Aspects of Luwian Religion. In C. Melchert. (Ed.), The Luwians. Hosane/Hosnme 68, Leiden: Brill: 211-280. 
Kohlmeyer, K. (2000). Der Tempel des Wettergottes von Aleppo. Gerda Henkel Vorlesung, Rhema.

Krahmalkov, C. R. (2001). A Phoenician-Punic Grammar. Leiden, Brill.

Kulakoğlu, F. (2001). Şanlıurfa Bölgesinde Yeni Keşfedilen M.Ö. I. Binyıl Heykeltraşlık Eserleri. TürkAED, 2, 22-34.

Lebrun, R. (1992). Baal Krntrysh. In E. Lipiński (Ed.), Dictionnaire de la civilisation phénicienne et punique. Turnhout: Brepo.

Lete, G. O., Sanmartín, J. (2015). A Dictionary of the Ugaritic Language in the Alphabetic Tradition. Third Revised Edition, Brill, Leiden - Boston.

Lipiński, E. (1970). La fête de l'ensevelissement et de la résurrection de Milqart. In Actes de la XVII Rencontre assyriologique internationale. Comité belge de recherches en Mésopotamie, 30-58.

- (1995). Dieux et déesses de l'univers phénicien et punique. Leuven: Uitgeverij Peeters.

- (1997). Semitic Languages: Outline of a Comparative Grammar. Leuven: Peeters.

Mosca, P. G., Russell, J. (1987). A Phoenician Inscription from Cebel Ires Dağ in Rough Cilicia. Epigraphica Anatolica, 9, 1-28.

O’Callaghan, R. (1949). The Great Phoenician Portal Inscription from Karatepe. Orientalia, 18(2), 173-205.

O'Connor, M. (1977). The Rhetoric of the Kilamuwa Inscription. Bulletin of the American Schools of Oriental Research, 226, 15-29.

Orthmann, W. (1971). Untersuchungen zur Späthethitischen Kunst. Bonn: Verlag.

Pohl, D. (2004). Baal und Zeus in Tarsos, Kulturbegegnung in einem Brückenland. Gottheitenund Kulte als Indikatoren von Akkulturationsprozessen im Ebenen Kilikien, Asia Minor Studien Band 53, Bonn, $63-73$.

Röllig, W. (1967). Karatepe. In H. Donner \& W. Röllig (Eds.), Kanaanäische und aramäische Inschriften (pp. 39-51). 2nd Edition. Vol. 3. Wiesbaden, Harrassowitz.

— (1983). The Phoenician Language: Remarks on the Present State of Research. Originalveröffentlichung in: Atti del I. Congresso Internationale di Studi Fenici e Punici / 2, Rom, 375-385.

— (1999). The Phoenician Inscriptions. In H. Çambel (Ed.), Corpus of Hieroglyphic Luwian Inscriptions Vol. II: Karatepe-Aslantaş. The Inscriptions, Berlin and New York: de Gruyter.

- (2001). Phönizisches aus Nordsyrien und der Gott Kurra. In K. Geus \& L. Zimmermann (Eds.), PunicaLibyca - Ptolemaica, Orientalia Lovaniensia Analecta, 104, 41-52.

- (2008). Zur phönizischen Inschrift von Cebelireis Dağ̀. In C. Roche (Ed.), D ‘Ougarit à Jérusalem, 51-56.

— (2011). Und ich baute starke Festungen an allen Enden auf den Grenzen...: Zur Bedeutung der Inschriften und Reliefs vom Karatepe-Aslantaş. Lag Troia in Kilikien? Darmstadt. 115-133.

Sayar, M.H. (1999). Kilikya’da Tanrılar ve Kültler. Olba 2, 131-154.

Schmitz, P. C. (2009). Phoenician KRNTRYŠ, Archaic Greek *KOPYNHTHPIO $\Sigma$, and the Storm God of Aleppo. In R. G. Lehmann (Ed.), Kleine Untersuchungen zur Sprache des Alten Testaments und seiner Umwelt, 10, 119-160.

Sivan, D. (2001). A grammar of the Ugaritic language. Secon Impression with Corrections, Brill, Leiden, Boston, Köln.

Swiggers, P. (1980). Noordwest-Semitisch, BiOr 37, 336-343. 
Tekoğlu, R., Lemaire, A., Ipek, I., Tosun, K. (2000). La bilingue royale louvito-phénicienne de Çineköy. Comptes rendus des séances de l'Académie des Inscriptions et Belles-Lettres, 144(3), 961-1006.

Vattioni, F. (1968). Note Fenicie. Annali dell'Istituto Orientale di Napoli, 18, 71-73.

Weeden, M. (2018). The Good God, the Wine-god and the Storm-god of the Vineyard. Die Welt des Orients, 48, H. 2, Viticulture and Wine in Hittite Anatolia and Its Ancient Near Eastern Context: Philological, Archaeological and Comparative Perspectives, 330-356.

Weippert, M. (1969). Elemente phönikischer und kilikischer Religion in den Inschriften vom Karatepe. ZDMG Supplementa I. XVII. Deutscher Orientalistentag. Wiesbaden, 191-217. Reprinted in Jahwe und die anderen Götter: Studien zur Religionsgeschichte des antiken. Forschungen zum Alten Testament 18. (Tübingen: Mohr Siebeck, 1997) 109-130.

Winter, I. J. (1979). On the Problems of Karatepe: The Reliefs and their Context. AS, 29, 115-151.

Yakubovich, I. S. (2008). Sociolinguistics of The Luvian Language. PhD thesis, The University of Chicago, Illinois.

Yakubovich, I. (2015). Phoenician and Luwian in Early Iron Age Cilicia. Anatolian Studies, 65, 35-53.

Younger, K. L. Jr. (2009). The Deity Kur(r)a in the First Millennium Sources. Journal of Ancient Near Eastern Religions, 9(1), 1-23. 


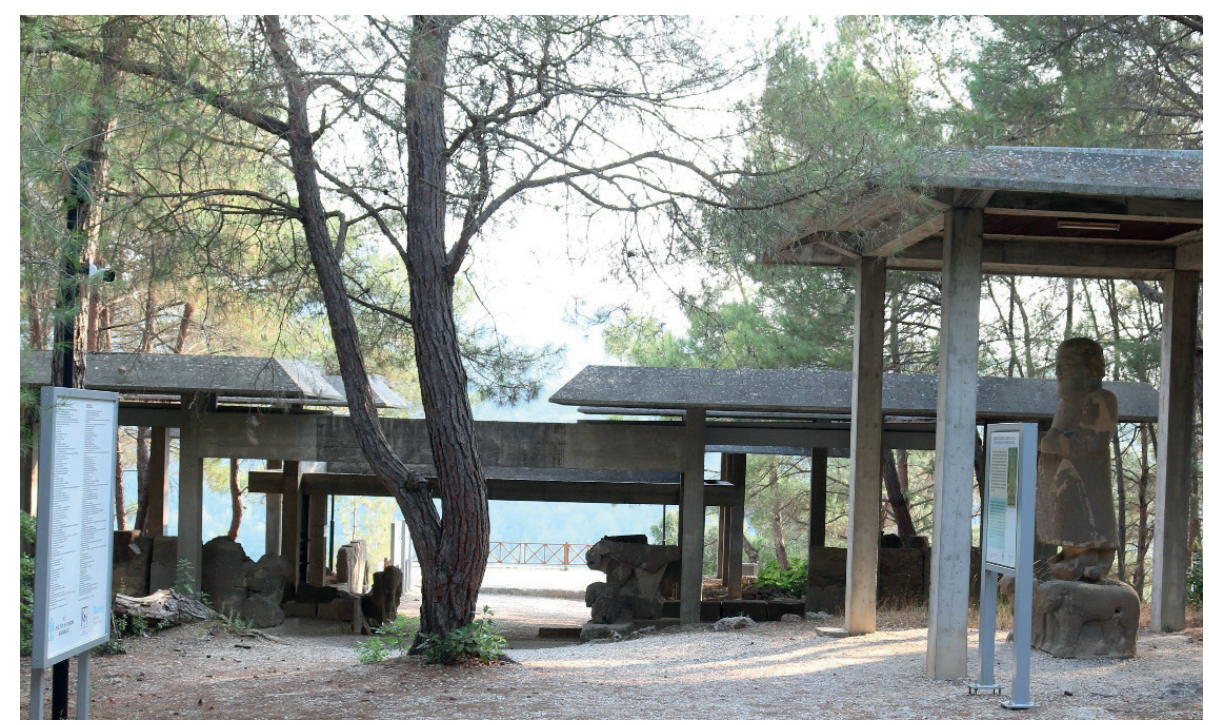

Figure 1. The storm god statue was placed behind the southeast gate

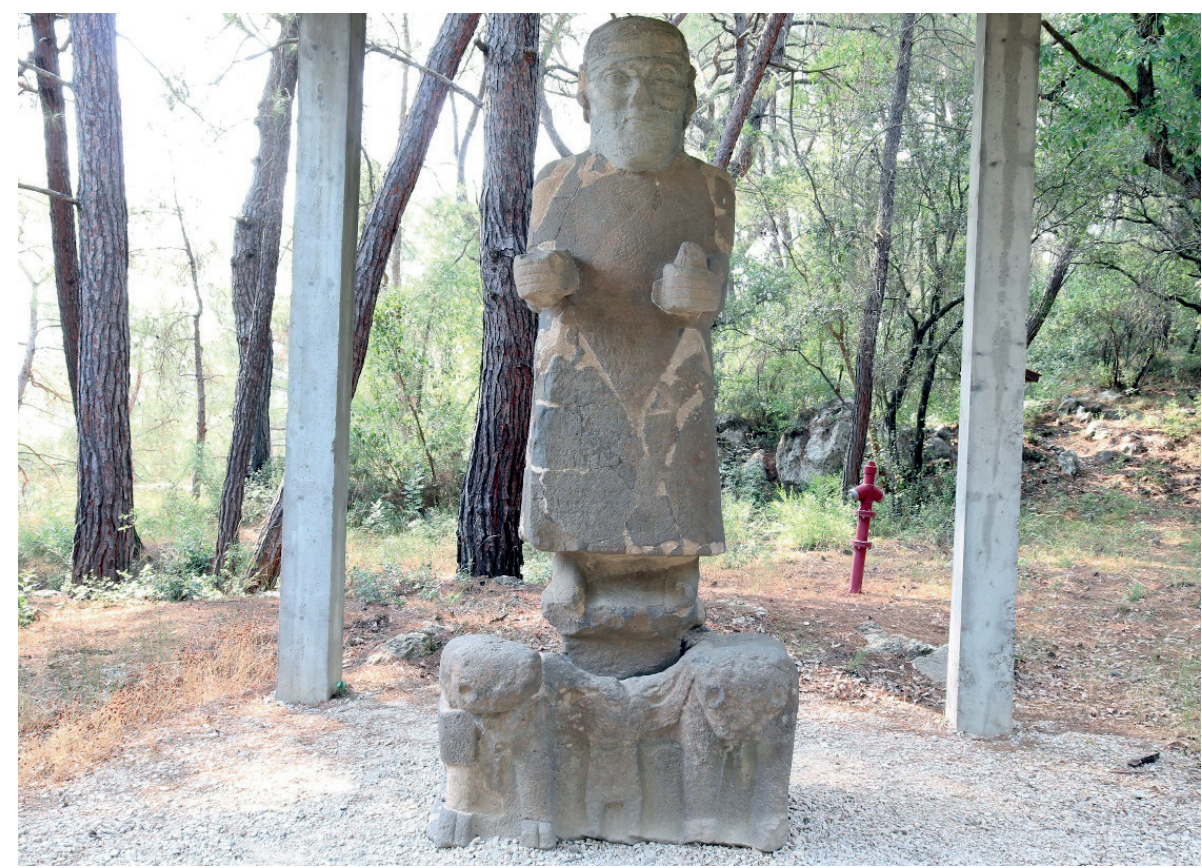

Figure 2. Statue of storm god Tarhunza Usanuwami/Baal Krntryš 


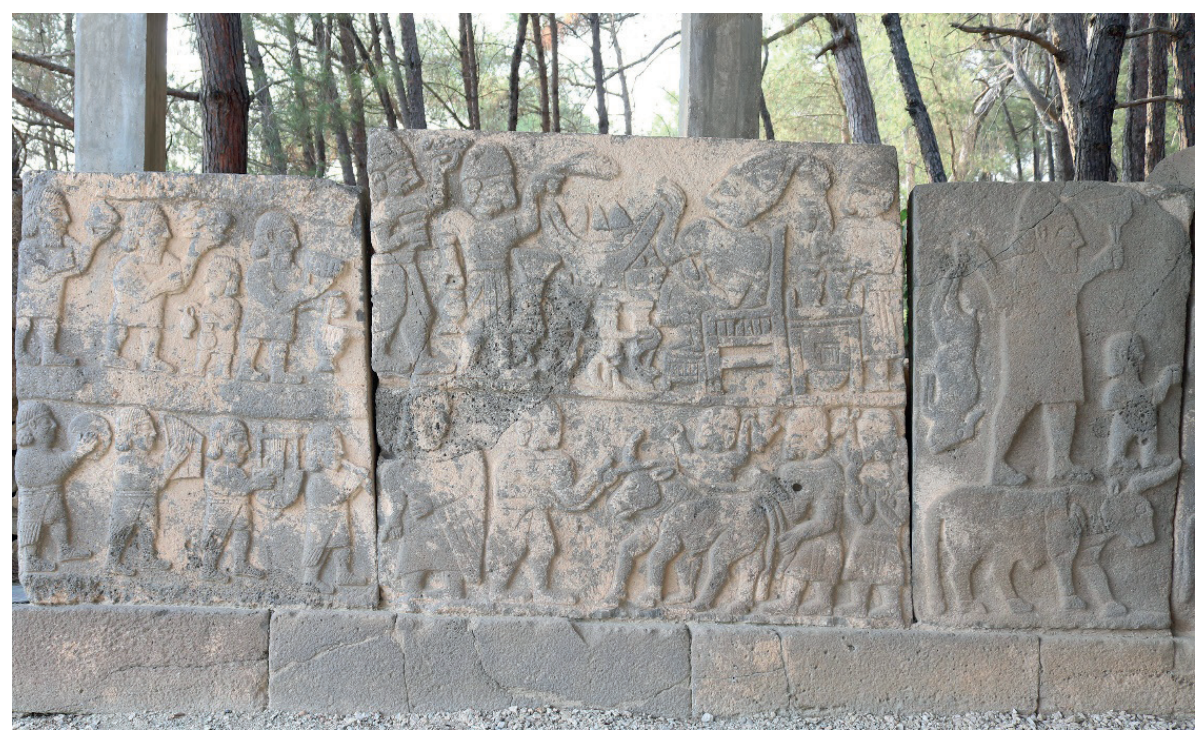

Figure 3. Storm god relief next to the banquet scene

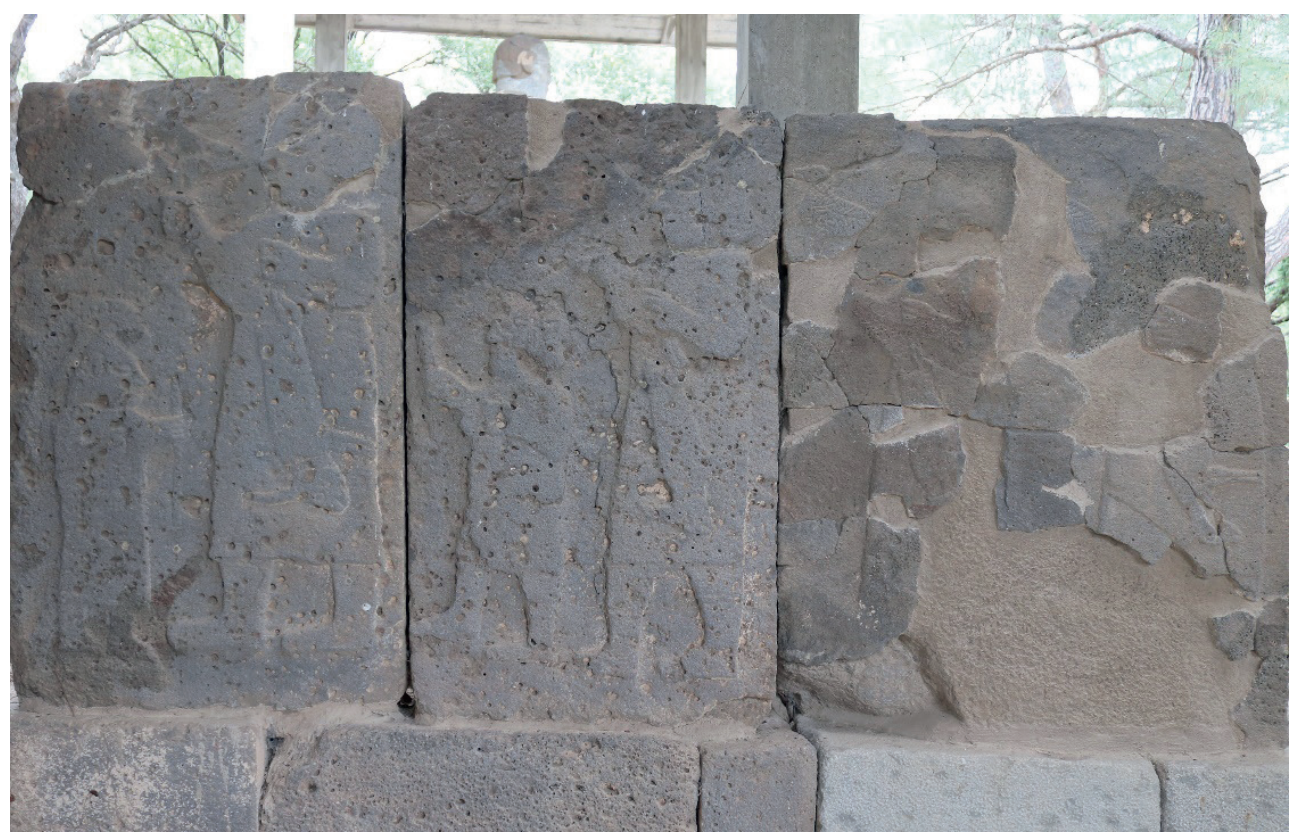

Figure 4. Reliefs of hunting god carrying hare and hawk 
